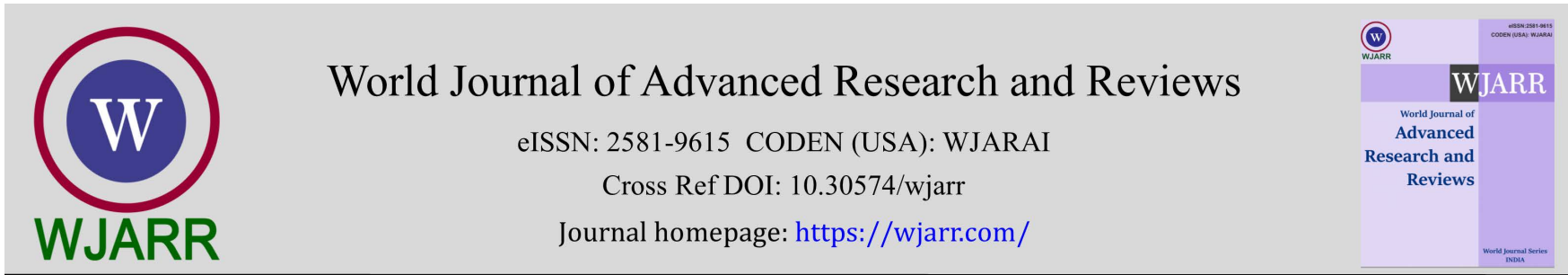

(RESEARCH ARTICLE)

Check for updates

\title{
Differential responses of two cowpea (Virgina unguiculata L.Walp.) genotypes to pre-emergence herbicides in the savannah woodland and rainforest agroclimatic regions of Sierra Leone
}

\author{
Dan David. Quee ${ }^{1,}{ }^{*}$, Philip Jimia. Kamanda ${ }^{2}$, Musa Decius. Saffa ${ }^{1}$ and Johnny Ernest. Norman ${ }^{1}$ \\ ${ }^{1}$ Njala University, School of Agriculture and Food Sciences, Crop Protection Department, Sierra Leone. \\ ${ }^{2}$ Njala University, School of Agriculture and Food Sciences, Department of Extension and Rural Sociology, Sierra Leone.
}

World Journal of Advanced Research and Reviews, 2021, 10(01), 343-355

Publication history: Received on 13 March 2021; revised on 22 April 2021; accepted on 25 April 2021

Article DOI: https://doi.org/10.30574/wjarr.2021.10.1.0161

\begin{abstract}
Field trials were conducted in savannah woodland (Njala) and rainforest (Serabu) agroclimatic regions of Sierra Leone during 2016 second cropping season to assess different preemergence herbicides techniques that is efficient, cost effective and environmentally safe in cowpea production. The experiment consisted of 20 treatments which included 2 cowpea genotypes (slipea 4 and slipea 5) and 10 different weed control techniques viz: butachlor 50\% emulsifiable concentrate (EC), double force ${ }^{\circ}$, power force $\circledR$ applied as preemergence herbicides at 2,4 and $6 \mathrm{~L} \mathrm{ha}^{-1}$, respectively and weedy check. The treatments were laid out in a strip-plot design arranged in a factorial system with three replications. The results of this study revealed that the application of power force ${ }^{\circledR}$ at $6 \mathrm{~L} \mathrm{ha}^{-1}$ recorded the highest phytotoxic effect, lowest weed dry weight, number of pods per plant and grain yield, highest total variable cost, lowest gross and net returns. Furthermore, butachlor 50\% EC at $2 \mathrm{~L} \mathrm{ha}^{-1}$ closely followed by double force $®$ at $6 \mathrm{~L} \mathrm{ha}{ }^{-1}$ resulted in maximum grain yield, gross and net returns compared to the rest of the other weed control techniques. Thus, it is concluded that butachlor 50\% EC at $2 \mathrm{~L} \mathrm{ha}^{-1}$ was more economical, profitable and beneficial than other control treatments in the production of cowpea genotypes in the savannah woodland and rainforest agroclimatic regions of Sierra Leone. Conclusively, the relationship between phytotoxicity and grain yield indicates that the higher the grain yield the lower the phytotoxic effects of the chemicals.
\end{abstract}

Keywords: Cowpea; Butachlor 50\% EC; Double force ${ }^{\circledR}$; Power force ${ }^{\circledR}$; Partial budget; Agroclimatic regions

\section{Introduction}

Cowpea (Vigna unguiculata (L) Walp.) belonging to fabaceae family and genus Vigna is one of the widely cultivated annual herbaceous legume crop in the savannah region of West Africa [1, 2, 3]. According to [4] and [5] the world estimated annual production of cowpea is about 4.5 million tonnes from a land area of 12.6 million hectares and West Africa accounts for about $80 \%$ of the estimated total land area under cowpea cultivation.

Among African leafy vegetables, cowpea hold high potential in solving food insecurity menace and improving livelihoods in Sub-Saharan Africa [6]. It is the most significant multifunctional and integral components of subsistence cropping system grown extensively under tropical and sub-tropical areas of the world [7]. Cowpea leaves can be used as fresh green vegetables, fermented or sun-dried and are rich in vitamins, macro and micro minerals, flavonoids, antioxidants, $ß$-carotene, fatty acids, amino acids, carbohydrates and dietary $[8,9,10,11]$.

\footnotetext{
${ }^{*}$ Corresponding author: Dan David Quee

Crop Protection Department, School of Agriculture and Food Sciences, Njala University, Sierra Leone. 
Nevertheless, the sustainable production of cowpea in Sierra Leone is limited by weed infestation, insect attack and low soil fertility [12]. Among these limitations, weeds constitute the most important constraints that influence cowpea production in the tropics as they compete with crops, reduce their growth rate, quantity and quality of grain yield as well as increase the cost of production due to insects and plant disease control [13, 14, 15, 16]. According to [17], competition of weeds with crops is mainly for available nutrients, moisture, space and sunlight, thus causing a significant crop yield loss. Yield losses caused by weeds alone in cowpea production can range from $25 \%$ to $76 \%$ depending on the cultivar and environment $[18,19,20,21]$. Weeds may also reduce crop yield by releasing allelopathic compounds into the environment [22] and by providing a conducive environment for pest and virus [23].

However, in Sierra Leone, resource poor cowpea farmers employ hand and hoe weeding for weed control, but this cultural method is time consuming, energy boring and overpriced. The use of chemical weed control in cowpea is limited due to scarcity of studies into the selectivity of herbicides for the crop $[24,25]$ and there are no registered herbicides for cowpea in Sierra Leone. Thus, one of the components of improved production technology is appropriate weed control, but weeds continue to render mayhem to the efforts geared towards increasing cowpea yield. Hence, the present study aimed at comparing different pre-emergence herbicides techniques in cowpea production, which should be efficient, cost effective and environmentally safe.

\section{Material and methods}

\subsection{Description of trial locations}

The field trials were conducted at Njala (N 08.12036, $\mathrm{W} 12.06727^{\circ}$ ) in the Moyamba district (Savannah woodland agroclimatic region) and Serabu (N 07.85249 ${ }^{\circ}$ W $011.27757^{\circ}$ ) Kenema district (Rainforest agroclimatic region) during the second cropping season (October 2016 to January 2017). The climatic conditions experienced in the study areas were two distinct seasons, rainy season (May-October) and dry season (November-April) not different from the rest of the country. Tables 1 and 2 shows the characteristics of the agroclimatic regions and physiochemical properties of the soil at the respective trial sites.

Table 1 Characteristics of the agroclimatic regions

\begin{tabular}{|l|l|l|}
\hline \multirow{2}{*}{ Characteristics } & Agroclimatic regions \\
\cline { 2 - 3 } Dominant land form & Njala (Savannah woodland) & Serabu (Rainforest) \\
\hline Altitude (m) & $\begin{array}{l}\text { Drainage depressions, undulating } \\
\text { plains, low plateau, and hills }\end{array}$ & $\begin{array}{l}\text { Plateau with undulating plains, } \\
\text { rolling plains and hills }\end{array}$ \\
\hline Mean temperature. $\left({ }^{\circ} \mathrm{C}\right)$ & $150-300$ & $300-600$ \\
\hline Average length of growing period (days) & 28.2 & 28.6 \\
\hline Dominant vegetation & $\begin{array}{l}\text { Lophira Savannah, Savannah } \\
\text { woodland, mixed tree Savannah upland } \\
\text { grassland and forest re- growth. }\end{array}$ & Forest and forest re- growth \\
\hline \multicolumn{1}{|c|}{ Source: [26] }
\end{tabular}

Table 2 Physiochemical properties of soil at the trial locations.

\begin{tabular}{|l|l|l|}
\hline \multirow{2}{*}{ Soil properties } & \multicolumn{2}{|l|}{ Trial locations } \\
\cline { 2 - 3 } & Serabu (Rainforest) & Njala (Savannah woodland) \\
\hline Soil physical properties & & \\
\hline Texture & Loamy sand & Sandy clay loam \\
\hline Sand (\%) & 88 & 68 \\
\hline Silt (\%) & 7 & 8 \\
\hline Clay (\%) & 5 & 14 \\
\hline
\end{tabular}




\begin{tabular}{|l|l|l|}
\hline Soil chemical properties & & \\
\hline Organic carbon $(\%)$ & 1.7 & 1.6 \\
\hline $\mathrm{pH}(1: 2: 5)$ & 5.1 & 4.48 \\
\hline Available Nitrogen $(\mathrm{mg} / \mathrm{kg})$ & 0.67 & 0.78 \\
\hline Available Phosphorus $(\mathrm{mg} / \mathrm{kg})$ & 2.5 & 0.09 \\
\hline Exchangeable Potassium $(\mathrm{mg} / \mathrm{kg})$ & 0.38 & 13.2 \\
\hline
\end{tabular}

\subsection{Experimental treatments and design}

The field trials were laid out in a strip-plot design arranged in a factorial system with three replications. The trials were made up of factor A which entails two genotypes of cowpea (slipea 4 and slipea 5) and factor B comprised of 10 weed control techniques (weedy check, butachlor at 2, 4 and $6 \mathrm{~L} \mathrm{ha}^{-1}$, double force ${ }^{\circledR}$ at 2, 4 and $6 \mathrm{~L} \mathrm{ha}^{-1}$, power force ${ }^{\circledR}$ at 2, 4 and $6 \mathrm{~L} \mathrm{ha}^{-1}$ and weedy check.

Table 3 Herbicides, recommended rate, active ingredient and time of application

\begin{tabular}{|c|c|c|c|}
\hline Herbicide trade name & Recommended rate $\left(\mathrm{L} \mathrm{ha}^{-1}\right)$ & Active ingredients (g a.i. $\mathrm{L}^{-1}$ ) & Time of application \\
\hline Double force ${ }^{\circledR}$ & $\begin{array}{l}4 \mathrm{~L} \mathrm{ha}^{-1} \text { in dilution with } 200- \\
250 \mathrm{~L} \mathrm{ha}^{-1} \text { of water }\end{array}$ & $\begin{array}{l}\text { Diuron }(350 \mathrm{~g} / \mathrm{l})+\text { Paraquat } \\
\text { dichloride }(150 \mathrm{~g} / \mathrm{l})\end{array}$ & Pre-emergence \\
\hline Power force ${ }^{\circledR}$ & $\begin{array}{l}4 \mathrm{~L} \mathrm{ha}^{-1} \text { in dilution with } 200- \\
250 \mathrm{~L} \mathrm{ha}^{-1} \text { of water }\end{array}$ & $\begin{array}{l}\text { Atrazine }(350 \mathrm{~g} / \mathrm{L})+\text { of } \\
\text { Paraquat dichloride }(140 \mathrm{~g} / \mathrm{L})\end{array}$ & Pre-emergence \\
\hline Butachlor 50\% EC & $\begin{array}{l}2.5-4 \mathrm{~L} \mathrm{ha}^{-1} \text { in dilution with } \\
250-600 \mathrm{~L} \mathrm{ha}^{-1} \text { of water }\end{array}$ & $\begin{array}{l}\text { NButoxy methyl 1-2-chloro-2, } \\
\text { 6-Diethyl acetanilide }\end{array}$ & Pre-emergence \\
\hline
\end{tabular}

\subsection{Experimental procedures}

The essential materials for the field trials were two cowpea genotypes (slipea 4 and slipea 5) obtained from the Njala Agricultural Research Centre (NARC), Njala, Sierra Leone. A compound fertilizer (NPK 15:15:15), herbicides (double force ${ }^{\circledR}$, power force ${ }^{\circledR}$ and butachlor $50 \% \mathrm{EC}$ ) and an insecticide (Chlorpyrifos $480 \mathrm{EC}$ ) were used and obtained from agrochemical stores in urban areas of Sierra Leone.

The trial sites were brushed, tilled and flattened to fine tilth with locally manufactured tools such as hoes, shovels, pickaxes and matchets. Each plot measured $3 \mathrm{~m} \times 2 \mathrm{~m}\left(6 \mathrm{~m}^{2}\right)$ with a distance of $0.5 \mathrm{~m}$ among plots and $1 \mathrm{~m}$ between replications giving an experimental area of $42.5 \mathrm{~m} \mathrm{x} 14.5 \mathrm{~m}\left(616.25 \mathrm{~m}^{2}\right)$ equivalent to approximately 0.06 ha. The genotypes were seeded at a spacing of $0.5 \mathrm{~m} \mathrm{x} 0.2 \mathrm{~m}$ inter and intra-row spacings with two seeds per hill on 14th October 2016. The preemergence herbicides were applied at the rates of 2,4 and $6 \mathrm{~L} \mathrm{ha}^{-1} \mathrm{in}$ a spray volume of water as a carrier at $200 \mathrm{~L} \mathrm{ha}^{-1}$ with the aid of knapsack sprayer (15 L capacity) using flat-fan nozzle on specified plots. These herbicide's rates were calculated using this formular: $Q=R \times A / C$. Where, $Q=Q$ uantity, $R=$ Rate of herbicide to be used, $A=A r e a$ of Land or Plot, C = Concentration of the herbicide formulation. A composite fertilizer (NPK 15:15:15) was applied at 2 weeks after sowing (WAS) at the rate of $200 \mathrm{~kg} \mathrm{ha}^{-1}$. Chlorpyrifos insecticide was applied at flowering and after pod formation at a rate of $2 \mathrm{~L} \mathrm{ha}^{-1}$ to control insect pests' attack. Harvesting was done manually in piecemeal on a net plot of $4 \mathrm{~m}^{2}$ at crop maturity, pods were sun dried for about 2 weeks after harvesting, threshing and winnowing was done subsequently to separate the seeds from the chaff.

\subsection{Data collected}

\subsubsection{Weed assessment}

The weed flora present in the experimental fields were collected and recorded at 4 and 8 WAP by randomly throwing a $0.25 \mathrm{~m}^{2}$ quadrat at three spots in each plot. The different weed species falling within the quadrat were scored, counted, identified and categorized to species levels and families at the herbarium unit of Njala University and with the aid of flora books [27]. The various species were harvested very close to the soil surface, air-dried and placed into paper bags separately per treatment. They are then oven dried at $65^{\circ} \mathrm{C}$ temperature to a constant weight and expressed in $\mathrm{g} \mathrm{m}^{-2}$.

Phytotoxicity (\%) = Total seedlings injured/number of initial seeds used x 100 . 
Number of pods per plant: The number of pods per plant were counted and recorded from the total pods of the abovetagged plants at harvest.

Grain yield ( $\left.\mathrm{kg} \mathrm{ha}^{-1}\right)$ : The grain yield was measured after threshing the sun-dried plants harvested from each net plot and the yield expressed in kilogram per hectare. Data for grain yield in $\mathrm{kg} \mathrm{ha}^{-1}$ were transformed by using the following formula applied by [28].

Grain yield $\left(\mathrm{Kg} \mathrm{ha}^{-1}\right)=$ Grain yield $(\mathrm{kg})$ from the net plot $/$ Harvested area $\left(\mathrm{m}^{2}\right) \times 10,000$

Economic analysis of cowpea production

Partial field trial budget analysis of the various treatments in both locations were calculated according to [29] and [30] formulas.

- $\quad$ Gross revenue $(\mathrm{GR})=$ Average grain yield in both locations $x$ current market price of cowpea (SLL $12,000 \mathrm{~kg}^{-1}$ )

- Total variable cost (TVC) = Sum of field cost (land preparation, cost of herbicides, cost of spraying, harvesting, threshing, winnowing and transportation etc.)

- $\quad$ Net return $(\mathrm{NR})=$ Gross revenue - Total variable cost

\subsubsection{Statistical analysis}

Data collected were subjected to combined analysis of variance (ANOVA) across agroclimatic regions using the PROC Mixed procedure of SAS version 9.4 [31]. Replications were treated as a random effect while agroclimatic regions, weed control methods and cowpea genotypes and their interactions were considered as fixed effects in determining the expected mean square and appropriate F-test. Means were separated using LSMEANS statement of PROC Mixed code of SAS with option pdiff at $\mathrm{P} \leq 0.05$. The statement calculates the difference between two means and the standard error of the difference (SED). Pearson's correlation coefficient between phytotoxicity and grain yield was computed using PRO CORR of SAS 9.4 [31].

\section{Results}

\subsection{Probability of F-values}

There were significant ( $\mathrm{P}<0.0001$ ) effects of location (L), weed control techniques (W), and their interactions on number of pods, weed dry weight, yield and phytotoxicity of cowpea. Genotype had no significant effect on number of pods, weed dry weight, yield and phytotoxicity of cowpea neither locations. In addition, the three-way interactions between genotype $\mathrm{x}$ weed control techniques $\mathrm{x}$ locations recorded no significant effect on number of pods, weed dry weight, yield and phytotoxicity of cowpea.

Table 4 Probability of F-values of response of number of pods plant ${ }^{-1}$, weed dry weight, phytotoxicity and grain yield of cowpea to genotypes, locations and weed control techniques at Njala and Serabu.

\begin{tabular}{|c|c|c|c|c|}
\hline Effect & Pods plant $^{-1}$ & Weed dry weight $\left(\mathrm{g} \mathrm{m}^{-2}\right)$ & Grain yield ( $t$ ha-1) & Phytotoxicity (\%) \\
\hline Genotype (G) & 0.9127 & 0.6421 & 0.5188 & 0.3281 \\
\hline $\begin{array}{l}\text { Weed control techniques } \\
\text { (W) }\end{array}$ & $<.0001$ & $<.0001$ & $<.0001$ & $<.0001$ \\
\hline Location (L) & $<.0001$ & $<.0001$ & $<.0001$ & $<.0001$ \\
\hline G x W & 0.5442 & 0.4616 & 0.9513 & 0.7703 \\
\hline GxL & 0.9810 & 0.7942 & 0.7254 & 0.4029 \\
\hline $\mathrm{W} \times \mathrm{L}$ & $<.0001$ & $<.0001$ & $<.0001$ & $<.0001$ \\
\hline$G \times W \times L$ & 0.4856 & 0.6488 & 0.8876 & 0.4179 \\
\hline
\end{tabular}




\subsection{Weed flora composition of cowpea}

The two field trials were conducted under naturally occurring diverse weed population and had a spectrum of 19 weed species representing 11 dissimilar families (Table 5). Among those species, 10 were widespread in both locations during 2016 second cropping season. These experimental field locations had an almost uniform infestation of weed species and were mostly dominated by broadleaves (63.16\%), grasses (26.32\%) and sedges (10.52\%). Additional analysis revealed that comparative composition of the broadleaf $(72.7 \%)$, sedges $(9.09 \%)$, and grasses $(18.2 \%)$ were recorded in Njala, whereas $61.1 \%, 27.8 \%$ and $11.1 \%$ were respectively recorded for broadleaves, grasses and sedges in Serabu.

Table 5 Weed species composition observed during second cropping at Njala and Serabu in 2016.

\begin{tabular}{|c|c|c|}
\hline Morphological group & Botanical name & Family \\
\hline \multirow[t]{12}{*}{ Broadleaves } & Calopogonium mucunoides & Fabaceae \\
\hline & Combretum spp & Combretaceae \\
\hline & Clerodendron scandens & Verbenaceae \\
\hline & Croton hirtus & Euphorbiaceae \\
\hline & Diodia scandens & Rubiaceae \\
\hline & Euphorbia heterophylla & Euphorbiaceae \\
\hline & Euphorbia hirta L. & Euphorbiaceae \\
\hline & Mimosa pudica L. & Fabaceae \\
\hline & Sida acuta & Malvaceae \\
\hline & Spigelia anthelma & Loganiaceae \\
\hline & Hyptis suaveolens & Lamiaceae \\
\hline & Phylanthus amarus & Euphorbiaceae \\
\hline \multirow[t]{5}{*}{ Grasses } & Andropogum tectorum & Poaceae \\
\hline & Digitaria ciliaris & Poaceae \\
\hline & Oxonoopus compressus & Poaceae \\
\hline & Panicum maximum & Poaceae \\
\hline & Elaeis guineensis & Arecaceae \\
\hline \multirow[t]{2}{*}{ Sedges } & Cyperus esculentus & Cyperaceae \\
\hline & Cyperus rotundus L. & Cyperaceae \\
\hline
\end{tabular}

\subsection{Weed dry weight $\left(\mathrm{g} \mathrm{m}^{-2}\right)$}

The results of the analysis of variance using mixed model procedures of SAS revealed highly significant $(\mathrm{P}<0.0001)$ effects of weed control techniques, location and their interactions on weed dry weight, whereas genotype and the threeway interactions among genotype $\mathrm{x}$ weed control techniques $\mathrm{x}$ location was not significant $(\mathrm{P}>0.6421$ and $\mathrm{P}>0.6488$, respectively). Similarly, genotype $x$ weed control techniques $(P>0.4616)$ and genotype $x$ location $(P>0.7942)$ did not show significant effects on weed dry weight of cowpea.

The minimum $\left(1.17 \mathrm{~g} \mathrm{~m}^{-2}\right)$ weed dry weight recorded across locations were from power force ${ }^{\circledR}$ at $6 \mathrm{~L} \mathrm{ha}^{-1}$ and double force $\circledast$ at $6 \mathrm{~L} \mathrm{ha}^{-1}$, which was statistically at par with the application of power force $₫$ at $4 \mathrm{~L} \mathrm{ha}^{-1}$. The analysis of variance using mixed model procedures of SAS further showed that the maximum $\left(16.69 \mathrm{~g} \mathrm{~m}^{-2}\right)$ weed dry weight obtained in weedy check was significantly $(\mathrm{P} \leq 0.05)$ higher than all the other weed control techniques (Table 6). Furthermore, we also observed that there was no significant difference $(\mathrm{P} \geq 0.05)$ in weed dry weight obtained from butachlor $50 \%$ EC at $4 \mathrm{~L} \mathrm{ha}^{-1}$ and power force $\AA$ at $2 \mathrm{~L} \mathrm{ha}^{-1}$ across genotype and locations. In the case of cowpea genotypes, slipea 4 genotype with high fodder and grain yield recorded significantly $(\mathrm{P} \leq 0.05)$ lower weed dry weight compared with slipea 5 at both locations. 
Table 6 Interactive effects of location, genotype and weed control techniques on total weed dry weight during second cropping season at Njala and Serabu in 2016.

\begin{tabular}{|c|c|c|c|c|c|}
\hline \multirow[b]{2}{*}{ Weed control techniques } & \multicolumn{2}{|l|}{ Njala } & \multicolumn{2}{|l|}{ Serabu } & \multirow[b]{2}{*}{ Mean } \\
\hline & Slipea 4 & Slipea 5 & Slipea 4 & Slipea 5 & \\
\hline Butachlor $50 \%$ EC at $2 \mathrm{~L} \mathrm{ha}^{-1}$ & 1.00 & 3.67 & 13.00 & 20.00 & 9.42 \\
\hline Butachlor $50 \% \mathrm{EC}$ at $4 \mathrm{~L} \mathrm{ha}^{-1}$ & 1.00 & 5.67 & 6.00 & 10.67 & 5.83 \\
\hline Butachlor $50 \% \mathrm{EC}$ at $6 \mathrm{~L} \mathrm{ha}^{-1}$ & 3.00 & 1.00 & 4.67 & 11.33 & 5.00 \\
\hline Double force ${ }^{\circledR}$ at $2 \mathrm{~L} \mathrm{ha}^{-1}$ & 1.00 & 2.00 & 3.67 & 1.67 & 2.08 \\
\hline Double force ${ }^{\circledR}$ at $4 \mathrm{~L} \mathrm{ha}^{-1}$ & 1.00 & 1.00 & 4.00 & 3.33 & 2.33 \\
\hline Double force ${ }^{\circledR}$ at $6 \mathrm{~L} \mathrm{ha}^{-1}$ & 1.00 & 1.33 & 1.00 & 1.33 & 1.17 \\
\hline Power force ${ }^{\circledR}$ at $2 \mathrm{~L} \mathrm{ha}^{-1}$ & 2.67 & 2.67 & 10.00 & 6.33 & 5.42 \\
\hline Power force ${ }^{\circledR}$ at $4 \mathrm{~L} \mathrm{ha}^{-1}$ & 1.00 & 1.00 & 1.33 & 1.33 & 1.33 \\
\hline Power force ${ }^{\circledR}$ at $6 \mathrm{~L} \mathrm{ha}^{-1}$ & 1.00 & 1.00 & 1.00 & 2.33 & 1.17 \\
\hline Weedy check & 5.67 & 6.11 & 33.33 & 21.67 & 16.69 \\
\hline Mean & 1.83 & 2.54 & 7.80 & 8.00 & \\
\hline SED: Genotype (G) & \multicolumn{5}{|l|}{0.69} \\
\hline SED: Weed control techniques (W) & \multicolumn{5}{|l|}{1.54} \\
\hline SED: Location (L) & \multicolumn{5}{|l|}{0.69} \\
\hline GxW $x \mathrm{~S}$ & \multicolumn{5}{|l|}{3.09} \\
\hline
\end{tabular}

\subsection{Phytotoxic effect (\%)}

Analysis of variance results on phytotoxicity exhibited highly significant $(\mathrm{P}<0.0001)$ effects of weed control techniques, location and their interactions, while analyzing the effect of each herbicide between genotypes no significant (P > 0.3281 ) effect was observed (Table 4).

Table 7 Phytotoxic effects of butachlor $50 \%$ EC, power force $\AA$ and double force $®$ on cowpea genotype at Njala and Serabu during second cropping season in 2016.

\begin{tabular}{|c|c|c|c|c|c|}
\hline \multirow[t]{2}{*}{ Weed control techniques } & \multicolumn{2}{|l|}{ Njala } & \multicolumn{2}{|l|}{ Serabu } & \multirow[b]{2}{*}{ Mean } \\
\hline & Slipea 4 & Slipea 5 & Slipea 4 & Slipea 5 & \\
\hline Butachlor $50 \%$ EC at $2 \mathrm{~L} \mathrm{ha}^{-1}$ & 10.56 & 11.11 & 32.22 & 21.11 & 18.75 \\
\hline Butachlor $50 \% \mathrm{EC}$ at $4 \mathrm{~L} \mathrm{ha}^{-1}$ & 8.33 & 8.33 & 31.11 & 33.33 & 20.28 \\
\hline Butachlor $50 \%$ EC at $6 \mathrm{~L} \mathrm{ha}^{-1}$ & 20.56 & 8.33 & 41.67 & 37.22 & 26.94 \\
\hline Double force ${ }^{\circledR}$ at $2 \mathrm{~L} \mathrm{ha}^{-1}$ & 12.22 & 17.22 & 28.33 & 24.44 & 20.56 \\
\hline Double force ${ }^{\circledR}$ at $4 \mathrm{~L} \mathrm{ha}^{-1}$ & 20.00 & 22.22 & 41.67 & 34.44 & 29.58 \\
\hline Double force ${ }^{\circledR}$ at $6 \mathrm{~L} \mathrm{ha}^{-1}$ & 14.44 & 22.78 & 60.00 & 47.22 & 36.11 \\
\hline Power force ${ }^{\circledR}$ at $2 \mathrm{~L} \mathrm{ha}^{-1}$ & 76.11 & 76.11 & 80.56 & 92.78 & 81.39 \\
\hline Power force ${ }^{\circledR}$ at $4 \mathrm{~L} \mathrm{ha}^{-1}$ & 92.22 & 91.67 & 97.78 & 97.22 & 94.72 \\
\hline Power force ${ }^{\circledR}$ at $6 \mathrm{~L} \mathrm{ha}^{-1}$ & 98.33 & 94.44 & 100.00 & 97.22 & 97.50 \\
\hline Weedy check & 14.44 & 12.78 & 17.78 & 17.78 & 15.69 \\
\hline Mean & 36.72 & 36.50 & 53.11 & 50.28 & \\
\hline SED: Genotype (G) & \multicolumn{5}{|l|}{1.09} \\
\hline SED: Weed control techniques (W) & \multicolumn{5}{|l|}{2.46} \\
\hline SED: Site (S) & \multicolumn{5}{|l|}{1.09} \\
\hline $\mathrm{G} \times \mathrm{W} \times \mathrm{S}$ & \multicolumn{5}{|l|}{4.91} \\
\hline
\end{tabular}


The interaction between herbicides for each genotype showed that power force ${ }^{\circledR}$ applied at 2, 4 and $6 \mathrm{~L} \mathrm{ha}^{-1}$, respectively provided $81.39 \%, 94.72 \%$ and $97.50 \%$ increase of crop injury (death) for both genotypes across locations, hence caused the highest levels of Phyto intoxication when compared to the weedy check plot (15.69\%). Comparing the genotypes for each weed control technique, at 14 days after planting, it was confirmed that weedy check was the least affected. At 2 WAP, slipea 4 cowpea genotype (53.11\% and 36.72\%) in Serabu and Njala, respectively was most sensible to the application of power force ${ }^{\circledR}$, which causes the death of most plants in both locations. Whereas those treated with double force ${ }^{\circledR}$ at $6 \mathrm{~L} \mathrm{ha}^{-1}$ caused very strong phytotoxical symptoms, affecting the development and triggered $36.11 \%$ plant death. Among the herbicides applied, our results discovered that butachlor $50 \% \mathrm{EC}$ at $2 \mathrm{~L} \mathrm{ha}^{-1}$ was significantly (P $\leq 0.05$ ) less phytotoxic to both genotypes across locations (Table 7).

\subsection{Number of pods per plant}

Across location and weed control techniques, the highest number of pods was significantly $(\mathrm{P}<.000)$ recorded from double force $\AA$ at $4 \mathrm{~L} \mathrm{ha}^{-1}\left(23.63\right.$ plant $\left.^{-1}\right)$ and was statistically at parity with double force $囚$ at $2 \mathrm{~L} \mathrm{ha}^{-1}\left(22.92\right.$ plant $\left.^{-1}\right)$. Furthermore, though butachlor $50 \% \mathrm{EC}$ at $4 \mathrm{~L} \mathrm{ha}^{-1}\left(21.58\right.$ plant $\left.^{-1}\right)$ and double force ${ }^{\circledR}$ at $6 \mathrm{~L} \mathrm{ha}^{-1}\left(21.33 \mathrm{plant}^{-1}\right) \mathrm{were}^{-}$ statistically similar, they significantly $(\mathrm{P} \leq 0.05)$ had higher number of pods than the other weed control techniques (Table 8). However, plots treated with Power force ${ }^{\circledR}$ at 2,4 and $6 \mathrm{~L} \mathrm{ha}^{-1}$ significantly $(\mathrm{P} \leq 0.05)$ recorded the lowest number of pods per plant in this study. Genotype and its interaction with weed control technique and locations did not show significant $(\mathrm{P}>0.05$ ) effects on number of pods per plant. However, slipea 5 genotype recorded higher number of pods per plant than slipea 4 across locations. The increased number of pods per plant at Njala may be attributed to the differences in the physiochemical properties of soil at the trial sites (Table 2).

Table 8 Interactive effect of genotype, weed control techniques and location on number of pods during second cropping season at Njala and Serabu in 2016.

\begin{tabular}{|c|c|c|c|c|c|}
\hline \multirow[b]{2}{*}{ Weed control techniques } & \multicolumn{2}{|l|}{ Njala } & \multicolumn{2}{|l|}{ Serabu } & \multirow[b]{2}{*}{ Mean } \\
\hline & Slipea 4 & Slipea 5 & Slipea 4 & Slipea 5 & \\
\hline Butachlor $50 \%$ EC at $2 \mathrm{~L} \mathrm{ha}^{-1}$ & 27.67 & 34.33 & 8.00 & 12.67 & 20.67 \\
\hline Butachlor $50 \%$ EC at $4 \mathrm{~L} \mathrm{ha}^{-1}$ & 33.00 & 35.00 & 10.67 & 7.67 & 21.58 \\
\hline Butachlor $50 \%$ EC at $6 \mathrm{~L} \mathrm{ha}^{-1}$ & 33.67 & 29.33 & 8.00 & 6.67 & 19.42 \\
\hline Double force ${ }^{\circledR}$ at $2 \mathrm{~L} \mathrm{ha}^{-1}$ & 30.67 & 44.00 & 9.67 & 7.33 & 22.92 \\
\hline Double force ${ }^{\circledR}$ at $4 \mathrm{~L} \mathrm{ha}^{-1}$ & 38.00 & 31.33 & 10.33 & 15.00 & 23.67 \\
\hline Double force ${ }^{\circledR}$ at $6 \mathrm{~L} \mathrm{ha}^{-1}$ & 36.67 & 34.00 & 6.67 & 8.00 & 21.33 \\
\hline Power force ${ }^{\circledR}$ at $2 \mathrm{~L} \mathrm{ha}^{-1}$ & 20.00 & 11.33 & 5.00 & 2.00 & 9.58 \\
\hline Power force ${ }^{\circledR}$ at $4 \mathrm{~L} \mathrm{ha}^{-1}$ & 1.00 & 1.00 & 1.33 & 1.00 & 1.08 \\
\hline Power force ${ }^{\circledR}$ at $6 \mathrm{~L} \mathrm{ha}^{-1}$ & 1.00 & 1.00 & 1.00 & 1.00 & 1.00 \\
\hline Weedy check & 30.33 & 32.22 & 6.00 & 6.33 & 18.72 \\
\hline Mean & 25.20 & 25.36 & 6.67 & 6.77 & \\
\hline SED: Genotype (G) & \multicolumn{5}{|l|}{0.82} \\
\hline SED: Weed control techniques (W) & \multicolumn{5}{|l|}{1.84} \\
\hline SED: Location (L) & \multicolumn{5}{|l|}{0.82} \\
\hline$G \times W \times L$ & \multicolumn{5}{|l|}{3.67} \\
\hline
\end{tabular}

\subsection{Grain yield ( $\left.\mathrm{kg} \mathrm{ha}^{-1}\right)$}

Results of the analysis of variance using proc mixed procedures of SAS showed highly significant $(\mathrm{P}<0.0001)$ effects of weed control techniques, location and their interactions on grain yield, while genotype was not significant ( $\mathrm{P}>0.5188$ ). The slipea 4 cowpea genotype attained the highest yield, while slipea 5 genotype had the least yield across locations and weed control techniques (Table 9). The diversity across genotype and weed control techniques exhibited that mean grain yield for individual location ranges from $4870 \mathrm{~kg} \mathrm{ha}^{-1}$ to $5030 \mathrm{~kg} \mathrm{ha}^{-1}$ at Njala and $1310 \mathrm{~kg} \mathrm{ha}^{-1}$ to $1360 \mathrm{~g} \mathrm{ha}^{-1} \mathrm{at}$ 
Serabu. The result indicates that available nitrogen $(\mathrm{mg} / \mathrm{kg})$ was $0.11 \mathrm{mg} / \mathrm{kg}$ greater at Njala than that of Serabu (Table 2) and rainfall was relatively higher in Serabu which might have caused flower abortion or destruction of pods (data not shown).

For weed control techniques, butachlor 50\% EC at $2 \mathrm{~L} \mathrm{ha}^{-1}\left(4220 \mathrm{~kg} \mathrm{ha}^{-1}\right)$ was the best and had the highest grain yield followed by double force ${ }^{\circledR}$ at $6 \mathrm{~L} \mathrm{ha}^{-1}\left(4140 \mathrm{~kg} \mathrm{ha}^{-1}\right)$ implying some gain in grain yield has been achieved, while power force ${ }^{\circledR}$ at $2 \mathrm{~L} \mathrm{ha}^{-1}, 4 \mathrm{~L} \mathrm{ha}^{-1}$ and $6 \mathrm{~L} \mathrm{ha}^{-1}$ attained the lowest grain yield $1690 \mathrm{~kg} \mathrm{ha}^{-1}, 1260 \mathrm{~kg} \mathrm{ha}^{-1}$ and $1000 \mathrm{~kg} \mathrm{ha}^{-1}$, respectively than weedy check treatment across both locations. The above results could be due to the little or no phototoxic effect of butachlor $50 \% \mathrm{EC}$ at $2 \mathrm{~L} \mathrm{ha}^{-1}$ and double force $\AA$ at $6 \mathrm{~L} \mathrm{ha}^{-1}$ herbicides on cowpea genotypes. In addition, the effectiveness of double force ${ }^{\circledR}$ at $6 \mathrm{~L} \mathrm{ha}^{-1}$ in the control of weeds decreased weed rivalry with the crop and led to better utilization of mineral nutrients, moisture and light, and better crop growth associated to the other treatments.

Table 9 Interactive effect of genotypes, weed control techniques and locations on grain yield of cowpea during second cropping season at Njala and Serabu in 2016.

\begin{tabular}{|c|c|c|c|c|c|}
\hline \multirow[b]{2}{*}{ Weed control techniques } & \multicolumn{2}{|l|}{ Njala } & \multicolumn{2}{|l|}{ Serabu } & \multirow[b]{2}{*}{ Mean } \\
\hline & Slipea 4 & Slipea 5 & Slipea 4 & Slipea 5 & \\
\hline Butachlor $50 \%$ EC at $2 \mathrm{~L} \mathrm{ha}^{-1}$ & 7.03 & 7.07 & 1.36 & 1.41 & 4220 \\
\hline Butachlor $50 \%$ EC at $4 \mathrm{~L} \mathrm{ha}^{-1}$ & 6.26 & 6.83 & 1.67 & 1.39 & 4040 \\
\hline Butachlor $50 \%$ EC at $6 \mathrm{~L} \mathrm{ha}^{-1}$ & 6.02 & 6.11 & 1.57 & 1.41 & 3780 \\
\hline Double force ${ }^{\circledR}$ at $2 \mathrm{~L} \mathrm{ha}^{-1}$ & 6.34 & 5.94 & 1.51 & 1.67 & 3870 \\
\hline Double force ${ }^{\circledR}$ at $4 \mathrm{~L} \mathrm{ha}^{-1}$ & 6.64 & 5.69 & 1.61 & 1.64 & 3900 \\
\hline Double force ${ }^{\circledR}$ at $6 \mathrm{~L} \mathrm{ha}^{-1}$ & 7.58 & 5.96 & 1.55 & 1.47 & 4140 \\
\hline Power force ${ }^{\circledR}$ at $2 \mathrm{~L} \mathrm{ha}^{-1}$ & 2.17 & 2.49 & 1.09 & 1.00 & 1690 \\
\hline Power force ${ }^{\circledR}$ at $4 \mathrm{~L} \mathrm{ha}^{-1}$ & 1.28 & 1.63 & 1.14 & 1.00 & 1260 \\
\hline Power force ${ }^{\circledR}$ at $6 \mathrm{~L} \mathrm{ha}^{-1}$ & 1.00 & 1.00 & 1.00 & 1.00 & 1000 \\
\hline Weedy check & 6.02 & 5.96 & 1.07 & 1.08 & 3540 \\
\hline Mean & 5030 & 4870 & 1360 & 1310 & \\
\hline SED: Genotype (G) & \multicolumn{5}{|l|}{0.12} \\
\hline SED: Weed control techniques (W) & \multicolumn{5}{|l|}{0.26} \\
\hline SED: Site (S) & \multicolumn{5}{|l|}{0.12} \\
\hline$G \times W \times S$ & \multicolumn{5}{|l|}{0.52} \\
\hline
\end{tabular}

\subsection{Phytotoxicity and grain yield relationship}

Grain yield was significant, weak and negatively correlated to phytotoxicity ( $\mathrm{P}=<.0001, \mathrm{r}=-0.66175)$, which shows that as cowpea grain yield increases, the lower the percentage of phytotoxicity. This indicates that, the higher the grain yield the lower the phytotoxic effects of the chemicals (Figure 1). The higher grain yield obtained from the butachlor $50 \%$ EC at $2 \mathrm{~L} \mathrm{ha}^{-1}$ and double force $\AA$ at $6 \mathrm{~L} \mathrm{ha}^{-1}$ could be attributed to the significantly lower percentage of phytotoxicity. Even though Butachlor 50\% EC $4 \mathrm{~L} \mathrm{ha}^{-1}$ treatment plots had significantly lower percentage of phytotoxicity, grain yields were significantly lower when compared to double force $®$ at $6 \mathrm{~L} \mathrm{ha}^{-1}$. This may have caused the weak strength of association between grain yield and phytotoxicity.

Partial budget analysis of different preemergence herbicides at various rates in the production of cowpea at Njala and Serabu is presented in Table 10 . Butachlor $50 \% \mathrm{EC}$ at $6 \mathrm{~L} \mathrm{ha}^{-1}$, double force $\circledR$ at $6 \mathrm{~L} \mathrm{ha}^{-1}$ and power force $\circledR$ at $6 \mathrm{~L} \mathrm{ha}-1$ recorded the highest total variable cost (SLL 4,420,000.00), followed by Butachlor $50 \% \mathrm{EC}$ at $4 \mathrm{~L} \mathrm{ha}^{-1}$, double force ${ }^{\circ}$ at $4 \mathrm{~L} \mathrm{ha}^{-1}$ and power force ${ }^{\circledR}$ at $4 \mathrm{~L} \mathrm{ha}^{-1}$ (SLL 3,970,000.00) respectively, compared with the other weed control techniques applied in this study. Whereas the lowest total variable cost was observed under weedy check (SLL 2,270,000.00) compared with the other treatments in both locations. 


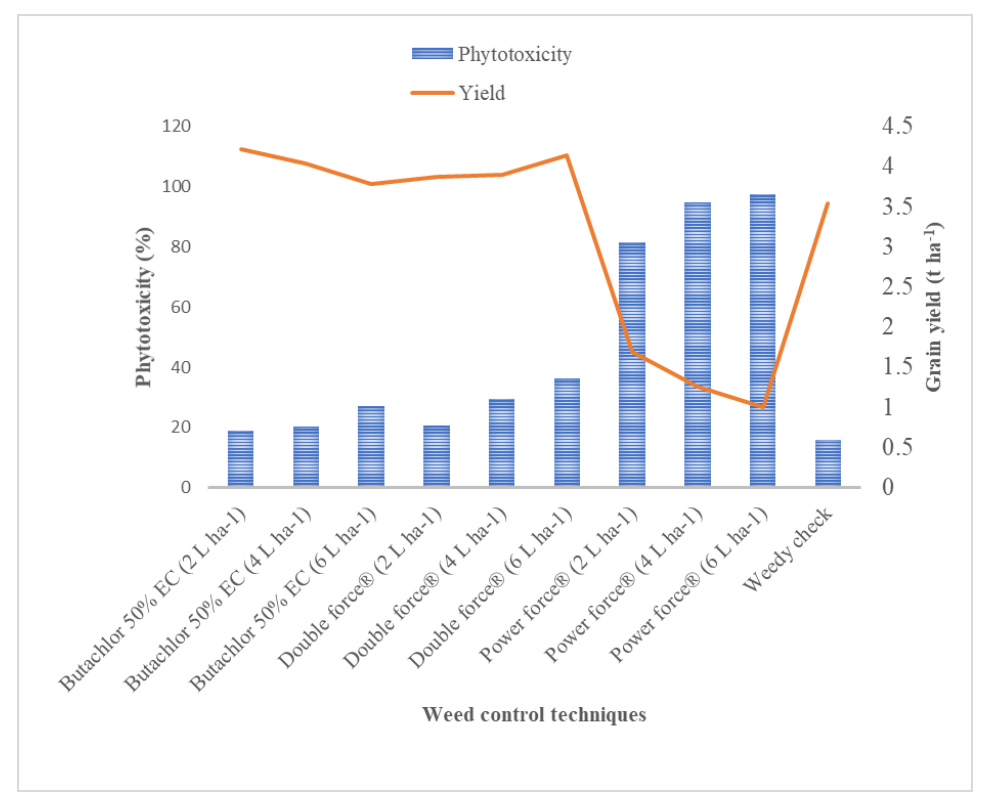

Figure 1 Relationship between phytotoxicity and grain yield as affected by weed control techniques.

Partial field budget analysis

Despite the high total variable cost of herbicides, butachlor $50 \% \mathrm{EC}$ at $2 \mathrm{~L} \mathrm{ha}^{-1}$ resulted in the highest gross return (SLL $50,640,000.00$ ) followed by double force ${ }^{\circledR}$ at $6 \mathrm{~L} \mathrm{ha}^{-1}$ (SLL 49,680,000.00), while power force $\AA$ at $6 \mathrm{~L} \mathrm{ha}{ }^{-1}$ (SLL $12,000,000.00$ ) recorded the lowest gross return compared to the rest of the treatments. Similarly, the highest net return was observed under butachlor 50\% EC at $2 \mathrm{~L} \mathrm{ha}^{-1}$ (SLL 47,120,000.00) followed by double force ${ }^{\circledR}$ at $6 \mathrm{~L} \mathrm{ha}{ }^{-1}$ (SLL $45,260,000.00)$, and lowest net return was recorded under power force $®$ at $6 \mathrm{~L} \mathrm{ha}^{-1}(\mathrm{SLL} 7,580,000.00)$ compared with weedy check treatment.

Table 10 Partial budget analysis of weed control techniques on cowpea genotypes at Njala and Serabu during second cropping season in 2016

\begin{tabular}{|c|c|c|c|c|c|}
\hline Herbicide & Rates (L ha-1) & $\begin{array}{l}\text { Grain yield (kg } \\
\text { ha-1) }^{-1}\end{array}$ & $\begin{array}{l}\text { Total variable } \\
\text { cost }\left(S L L \text { ha }^{-1}\right)\end{array}$ & $\begin{array}{l}\text { Gross return } \\
(\text { SLL ha-1) }\end{array}$ & $\begin{array}{l}\text { Net return (SLL } \\
\text { ha' }^{-1} \text { ) }\end{array}$ \\
\hline \multirow[t]{3}{*}{ Butachlor 50\% EC } & 2 & 4220 & $3,520,000.00$ & $50,640,000.00$ & $47,120,000.00$ \\
\hline & 4 & 4040 & $3,970,000.00$ & $48,480,000.00$ & $44,510,000.00$ \\
\hline & 6 & 3780 & $4,420,000.00$ & $45,360,000.00$ & $40,940,000.00$ \\
\hline \multirow[t]{3}{*}{ Double force® } & 2 & 3870 & $3,520,000.00$ & $46,440,000.00$ & $42,920,000.00$ \\
\hline & 4 & 3900 & $3,970,000.00$ & $46,800,000.00$ & $42,830,000.00$ \\
\hline & 6 & 4140 & $4,420,000.00$ & $49,680,000.00$ & $45,260,000.00$ \\
\hline \multirow[t]{3}{*}{ Power force® } & 2 & 1690 & $3,520,000.00$ & $20,280,000.00$ & $-3,499,720.00$ \\
\hline & 4 & 1260 & $3,970,000.00$ & $15,120,000.00$ & $11,150,000.00$ \\
\hline & 6 & 1000 & $4,420,000.00$ & $12,000,000.00$ & $7,580,000.00$ \\
\hline Weedy check & & 3540 & $2,270,000.00$ & $42,480,000.00$ & $40,210,000.00$ \\
\hline
\end{tabular}

\section{Discussion}

Naturally occurring weed flora of the study locations indicated 19 different weed species belonging to 11 families. Broadleaf was the most prevalent group accompanied by grasses and sedges. The disparities in the weed composition may be attributed to differences in agroecological conditions, management practices and weed seed bank composition between the study locations. These results further buttressed the observations of [32], [33] and [34] who reported that 
relative weed community in aerobic rice is generally dominated by broadleaf weeds followed by sedges and grasses. Similar observations have been reported by ]35] in their studies of weed control in tomato.

Though weed dry weight was reduced by the application of power force ${ }^{\circledR}$ at $6 \mathrm{~L} \mathrm{ha}^{-1}$ and double force ${ }^{\circledR}$ at $6 \mathrm{~L} \mathrm{ha}^{-1}$ treatments, vigorous cowpea growth and yield was not significantly encouraged due to high phytotoxicities. The current research result was in line with [36] who reported lower weed dry matter and higher weed control efficiency with herbicides used. In addition, [37] similarly stated that pre-emergence herbicides reduced the weed dry weight significantly as compared to weedy check in common bean. The higher weed biomass observed in the weedy check could be attributed to uncontrolled weeds measure on weed growth [38]. These results are consistent with the findings of [39] who testified more weed dry biomass in weedy check than pre-emergence herbicides application in Brassica napus L. for weed management. Slipea 4 cowpea genotype significantly recorded lower weed dry weight compared with slipea 5, which was in agreement with the findings of [36] that adequate weed cover by cowpea vine led to smothering effect of the weeds judging from the low weed population and low weed dry weight, which invariably led to increase in weed smothering efficiency.

The results presented in Table 7 clearly demonstrated that phytotoxic effect on cowpea increased linearly with the concentrations of butachlor $50 \%$ EC, power force ${ }^{\circledR}$ and double force ${ }^{\circledR}$. The current result showed that chemo toxic effects of various herbicides when applied at different rates had variable effects on cowpea production by alternating their ecology [40]. The magnitude of the toxic effects of herbicides, however, depends primarily on the type and dose of compounds, duration of exposure, species and age of plants, and other environmental factors [41]. Our result corroborates with [42] who reported that Diuron was highly adsorbed in the soil profile and available for plant uptake during the growth season, thus a more phototoxic effect to the test plant was found.

The current results in Table 8 agrees with the findings of [43] and [44] who reported the highest number of pods per plant with single herbicide in peanut (Arachis hypogaea L.) and soybean, respectively. This can be attributed to the fact that effective weed management may lead to appropriate environment for growth and photosynthetic activity of the crop resulting to enhancement in the number of pods per plant. The lowest number of pods per plant recorded from power force ${ }^{\circledR}$ at $4 \mathrm{~L} \mathrm{ha}^{-1}$ and $6 \mathrm{~L} \mathrm{ha}^{-1}$ respectively, was not as a result of the presence of weeds, but due to the toxic effect of herbicide. However, [45] showed that the incidence of weeds is a prominent factor in reducing the number of pods in cowpea plant. Hereafter, [46] had reported that weeding suppressed or minimized the growth, development and competitive capacity of weeds thereby enhancing optimum pod yield. Additionally, [47] reported that chemical weeding at 2-3 leaf stage resulted highest value of number of pods plant ${ }^{-1}$.

There are a number of reports on influence of herbicides on yield parameters and crop yield. In this regard, the grain yield of cowpea genotypes showed a substantial level of disparity due to differential genetic makeup of the crops or influence of the location since yield is quantitatively hereditary [48, 38] and [35]. However, [49] likewise found that genetic effects and ecological factors affected agronomic performance of cowpea genotypes. Thus, slipea 4 cowpea genotype was a spreading type with more fruit bearing branches, and hence higher fodder and grain yield [50]. Furthermore, differences in grain yield may be due to inconsistencies in soil fertility and rainfall in the two locations. The changes in genotype performance across different locations reduce the relationship between genotypes and their corresponding phenotypes $[51,52]$. The poor yield by power force ${ }^{\circledR}$ at $2 \mathrm{~L} \mathrm{ha}^{-1}, 4 \mathrm{~L} \mathrm{ha}^{-1}$ and $6 \mathrm{~L} \mathrm{ha}^{-1}$ may be attributed to the phytotoxic effects of this herbicide [53]. Furthermore, [54] similarly reported that application of Pendimethalin @ $0.75 \mathrm{~kg}$ a.i./ha as pre-emergence gave broad spectrum control of weeds and resulted in higher cowpea seed yield. Likewise, [55] also concluded that the highest seed yield of cowpea was recorded from plots that received chemical weeding.

Chemical weed control proved the most practical in recent years due to lower cost and effectiveness at lower dose gives economic return in controlling weeds. The current results shown in Table 10 indicated that the use of herbicide is more gainful in the production of cowpea than other weed control techniques, thus butachlor 50\% EC at $2 \mathrm{~L} \mathrm{ha}^{-1}$ and double force $®$ at $6 \mathrm{~L} \mathrm{ha}^{-1}$ resulted in the highest gross return. This result is similar to the findings of [56] who reported that herbicides for weed control in cowpea can result in highly effective control, lower production costs, optimum and highest net returns compared with the other methods of weed control treatments.

\section{Conclusion}

From this study, it can be concluded that power force ${ }^{\circledR}$ at $6 \mathrm{~L} \mathrm{ha}^{-1}$ recorded the highest phytotoxic effect, lowest weed dry weight, decreased number of pods per plant and grain yield, highest total variable cost, lowest gross and net returns. Furthermore, butachlor 50\% EC at $2 \mathrm{~L} \mathrm{ha}^{-1}$ closely followed by double force ${ }^{\circledR}$ at $6 \mathrm{~L} \mathrm{ha}^{-1}$ resulted in the highest grain yield, gross return and net returns compared to the rest of the other weed control techniques in both locations. However, 
butachlor $50 \% \mathrm{EC}$ at $6 \mathrm{~L} \mathrm{ha}^{-1}$, double force $®$ at $6 \mathrm{~L} \mathrm{ha}^{-1}$ and power force $\AA$ at $6 \mathrm{~L} \mathrm{ha}^{-1}$ were more expensive and resulted in the highest cost of cowpea production than all the herbicide treatments and weedy check. Thus, butachlor $50 \%$ EC at $2 \mathrm{~L} \mathrm{ha}^{-1}$ followed by double force ${ }^{\circledR}$ at $6 \mathrm{~L} \mathrm{ha}^{-1}$ were more economical, profitable and beneficial than other control treatments in the production of cowpea in the savannah woodland and rainforest agroclimatic regions of Sierra Leone. The relationship between phytotoxicity and grain yield indicates that the higher the grain yield the lower the phytotoxic effects of the chemicals.

\section{Compliance with ethical standards}

\section{Acknowledgments}

We are very appreciative to Njala Agricultural Research Centre (NARC) for allowing us to conduct this study in their trial sites.

\section{Disclosure of conflict of interest}

Dan David. Queea, Philip Jimia. Kamanda, Musa Decius. Saffa, and Johnny Ernest Norman have respectively declared no conflict of interest.

\section{References}

[1] Muoneke CO, Ndukwe 00, Umana PE, Okpara DA, Asawalam D O. Productivity of vegetables cowpea (Vigna unguiculata L. Walp.) and maize (Zea mays L.) intercropping system as influenced by component density in a tropical zone of southeastern Nigeria. International Journal of Agricultural Research and Development. 2012; 15: 835-847.

[2] Adusei G, Gaiser T, Boukar O, Fatokun C. Growth and yield responses of cowpea genotypes to soluble and rock P fertilizers on acid, highly weathered soil from humid tropical West Africa. International Journal of Biological and Chemical Sciences. 2016; 10(4): 1493-1507.

[3] Abudulai M, Kusi F, Seini SS, Seidu A, Nboyine JA, Larbi A. Effects of planting date, cultivar and insecticide spray application for the management of insect pests of cowpea in northern Ghana. Crop Protection. 2017; 100: 168176.

[4] FAO. Statistical Data Base. Food and Agricultural Organization of the United Nations. Osipitan OA. Weed Interference and Control in Cowpea Production: A Review jas.ccsenet.org Journal of Agricultural Science. 2017; 9(12).

[5] Grivetti LE, Ogle BM. Value of traditional foods in meeting macro-and micronutrient needs: the wild plant connection. Nutrition Research Reviews. 2017; 13: 31e46.

[6] Rathore DK, Kumar R, Singh M, Meena VK, Kumar U, Gupta S P, Yadav T, Makarana G. Phosphorus and zinc fertilization in fodder cowpea - A review. Agricultural Review. 2015; 36(4): 333-338.

[7] Saidi M, Itulya FM, Aguyoh JN, Ngouajio M. Effects of cowpea leaf harvesting initiation time and frequency on tissue nitrogen content and productivity of a dual-purpose cowpea-maize intercrop. HortScience. 2010; 45: 369375 .

[8] Okonya JS, Maass BL. Protein and iron composition of cowpea leaves: an evaluation of six cowpea varieties grown in Eastern Africa. African Journal of Food, Agriculture, Nutrition and Development. 2014.

[9] Goncalves A, Goufo P, Barros A, Domínguez-Perles R, Trindade H, Rosa EAS, Ferreira L, Rodrigues M. Cowpea (Vigna unguiculata L. Walp), a renewed multipurpose crop for a more sustainable agri-food system: nutritional advantages and constraints. Journal of the Science of Food and Agriculture. 2016; 96: $2941 \mathrm{e} 2951$.

[10] Wafula EN, Franz CMAP, Rohn S, Huch M, Mathara JM, Trierweiler B. Fermentation of African indigenous leafy vegetables to lower post-harvest losses, maintain quality and increase product safety. African Journal of Horticultural Science. 2016; 9.

[11] Ukeh DA, Adie EB, Ukeh JA. Insecticidal and Repellent Activities of Pepper Fruit, Dennetia tripetala (G. Baker) against Cowpea Beetle, Callosobruchus maculatus (Fabricius). Biopesticide International. 2011; 7(1): 15-23.

[12] Zadeh Ghani H, Lorzadeh S, Aryannia N. Evaluating Weeds Competitive Ability in a Corn Field in Southern West of Iran. Asian Journal of Crop Science. 2011; 3(4): 179-187. 
[13] Patil BC, Padanad LA, Yashvantkumar KH, Soumya S, Ravi L. Efficacy and economics of integrated weed management in vegetable cowpea [Vigna unguiculata (L.) Walp]. Agriculture Update. 2014; 9(1): 124-127.

[14] Getachew M, Sharma JJ, Lisanework N, Tamado T. Effect of integrated weed management practices on weeds infestation, yield components and yield of cowpea [Vigna unguiculata (L.)

[15] Walp.] in eastern Wollo, northern Ethiopia. American Journal of Experimental Agriculture. 2015; 7(5): 326-346.

[16] Singh S, Gupta A, Singh BB. Effect of foliage supplementation to Heteropogon contortus based diets on nutrients digestibility, gas and metabolites production in sheep and goat inoculums. Animal Nutrition and Feed Technology. 2016; 16(3): 439-450.

[17] Khan IA, Marwat KB, Hassan G, Khan R, Ullah Z. Suppressive capability of herbicides and plant extracts against chickpea weeds. Journal of Animal and Plant Sciences. 2012; 22(2): 67-9.

[18] Adigun J, Osipitan AO, Lagoke ST, Adeyemi RO, Afolami SO. Growth and yield performance of cowpea (Vigna unguiculata (L.) Walp) as influenced by row spacing and period of weed interference in South-West Nigeria. Journal of Agricultural Science. 2014; 6(4): 188.

[19] Gupta KC, Gupta AK, Rani, S. Weed management in cowpea [Vigna unguiculata (L.) Wasp.]Under rainfed conditions. International Journal of Agricultural Sciences. 2016; 12(2): 238-240.

[20] Osipitan OA, Adigun JA, Kolawole RO. Row spacing determines critical period of weed control in crop: Cowpea (Vigna unguiculata) as a case study. Azarian Journal of Agriculture. 2016; 3(5): 90-96.

[21] Ugbe LA, Ndaeyo NU, Enyong JF. Efficacy of Selected Herbicides on Weed Control, Cowpea(Vigna unguiculata L. Walp) Performance and Economic Returns in Akamkpa, Southeastern Nigeria. International Journal. 2016; 19: 19-27.

[22] Marinov-Serafimov P. Determination of allelopathic effect of some invasive weed species on germination and initial development of grain legume crops. Pesticidi I Fitomedicina. 2015; 25(3): 251-259.

[23] Fisichelli NA, Abella SR, Peters M, Krist FJ. Climate, trees, pests, and weeds: Change, uncertainty, and biotic stressors in eastern US national park forests. Forest Ecology and Management. 2014; 327: 31-39.

[24] Silva PSL, Oliveira OF, Silva PIB, Silva KMB, Braga JD. Effect of cowpea intercropping on weed control and corn yield. Indian Journal of Weed Science. 2009; 27(3): 491-497.

[25] Sousa MBE, Damasceno-Silva KJ, Rocha MDM. Genotype by environment interaction in cowpea lines using GGE biplot method. Rev Caatinga. 2017; 31: 64-71.

[26] IFPRI (International Food Policy Research Institute). Rebuilding after Emergency Revamping Agricultural Research in Sierra Leone after Civil War. IFPRI Discussion Paper 00869 May 2009.

[27] Melaku W. A preliminary guide to plant collection, identification and herbarium techniques. In The National Herbarium Addis Ababa University, Ethiopia. Addis Ababa University, Faculty of Science, Biology Department. 2008.

[28] Khan I, Khan MI, Ullah H, Haroon M, GuL B. Assessment of integrated weed management approaches on Asphodelus tenuifolius in chickpea. Plant Daninha. 2017; v36: e018179088.

[29] Moro BM, Nuhu IR, Toshiyuki W. Determining optimum rates of mineral fertilizers for economic rice grain yields under the "Sawah" System in Ghana. West African Journal of Applied Ecology. 2008; 12: 1-12.

[30] Osipitan OA, Yahaya I, Adigun JA. Economics of Weed Management Methods as Influenced by Row-Spacing in Cowpea. Journal of Agricultural Science. 2018; 10(2): 2018.

[31] SAS Institute. SAS/STAT User's Guide: Statistics. Version 9.4, SAS Institute, USA. 2012.

[32] Sunil CM, Shekara BG, Kalyanamurthy KN, Shankaralingappa BC. Growth and Yield of Aerobic Rice as Influenced by Integrated Weed Management Practices. Indian Journal of Weed Science. 2010; 42: 180-183.

[33] Jayadeva HM, Bhairappanavar ST, Hugar AY, Rangaswamy BR, Mallikarjun GB, Malleshappa C, Channa ND. Integrated Weed management in Aerobic Rice (Oryza sativa L.).Agriculture Science Digest. 2011; 31: 58-61.

[34] Anwar MP, Juraimi AS, Samedani B, Puteh A, Man A. “Critical period of weed control inaerobic rice,” The Scientific World Journal. 2012; vol. 2012, Article ID 603043, 10 pages. 
[35] Olayinka BU, Esan 00, Anwo I0, Etejere EO. Comparative growth analysis and fruit quality of two varieties of tomato under hand weeding and pendimenthalin herbicide. Journal of Agricultural Science 2017; 12(3): 149161.

[36] Sunday O, Udensi E. Evaluation of Pre-Emergence Herbicides for Weed Control in Cowpea[Vigna unguiculata (L.) Walp.] in a Forest -Savanna Transition Zone. American Journal of Experimental Agriculture. 2013; 3: 767-779.

[37] Jafari R, Rezai S, Shakarami J. Evaluating effects of some herbicides on weeds in field bean (Phaseolus vulgaris L.). International Research Journal of Applied and Basic Science. 2013; 6: 1150-1152.

[38] Olayinka BU, Etejere EO. Growth analysis and yield of two varieties of groundnut (Arachis hypogaea L.) as influenced by different weed control methods. Indian Journal of Plant Physiology. 2015; 20(2), 130-136.

[39] Marwat KB, Saeed M, Gul B, Hussain Z, Khan NI. Efficacy of different pre- and post-emergence herbicides for weed management in canola in higher altitude. Pakistan Journal of Weed Sciences Research. 2005; 11: 165-170.

[40] Khan I, Hassan G, Khan MA, Khan IA. Efficacy of some new herbicidal molecules on grassy and broad leaf weeds in wheat crop-II. Pakistan Journal of Weed Science Research. 2004; 10 (12): 33-38.

[41] Sahoo DP, Kumar S, Mishra S, Kobayashi Y, Panda SK, Sahoo L. Enhanced salinity tolerance in transgenic mungbean over expressing Arabidopsis antiporter (NHX1) gene. Mol. Breed. 2016; 36: 144.

[42] El-Nahhal Y, Abadsa M, Affifi S. Adsorption of diuron and linuron in Gaza soils. American Journal of Analytical Chemistry. 2013; 4: 94-99.

[43] Priya RS, Chinnusamy C, Manickasundaram P, Babu C. A review on weed management in groundnut (Arachis hypogea L.). International Journal of Agricultural Science and Research. Mar 2013; 3(1): 163-172.

[44] Abouziena HF. Effect of Sowing Date and Reduced Herbicides Rate with Additives on Peanut(Arachis Hypogaea L.) Productivity and Associated Weeds, Journal of Applied Sciences Research. 2013; 9(3): 2176-2187,

[45] Mirshekari B. Time interaction effect of (Amaranthus retroflexus L.) weed on yield of cowpea[Vigna unguiculata (L.) Walp.]. Knowledge of Modern Agriculture Journal. 2008; 4: 71-81.

[46] Dugje IY, Omoigui LO, Ekeleme F, Bandyopadhyay RP, Lava K. Kumar AY. Farmers Guideto Soya bean Production in Northern Nigeria. 2009. International Institute of Tropical Agriculture, 7.

[47] Madukwe DK. Effects of water stress on the nodulation potentials and performance of some legume crops. M.Sc. Thesis Department of Crop Science and Biotechnology. Faculty of Agriculture and Veterinary Medicine, Imo State University, Owerri-Nigeria. 2010.

[48] Hernandez SM, Rodriguez EM, Rodriguez Diaz R. Chemical composition of tomato (Lycopersicon esculentum). In: Tenerife, The Canary Islands. Food Chemistry. 2008; 106: 1046-1056.

[49] Barros MA, Rocha R, Gomes RLF, Silva KJD, Neves A. Adaptability and production stability of semi-prostrate cowpea beans. Brazil Agricultural Research. 2013; 48: 403-410.

[50] Acquah G. Principles of Plant Genetics and Breeding. Blackwell Publishing USA. 2007.

[51] Abate F, Mekbib F, Dessalegn Y. Association of different parametric and non-parametric stability models in durum wheat (Triticum turgidum Desf.) genotypes. International Journal of Plant \& Soil Science. 2015; 7(4): $192-201$.

[52] Aramendiz TH, Miguel EC, Carlos CA. Adaptation and stability of cowpea ('Vigna unguiculata' (L.) Walp) bean cultivars in the tropical dry forest of Colombia. Australian Journal of Crop Science. 2019; 13: 1009-1016.

[53] Imoloame EO. Effects of pre- and post- emergence herbicides on weed infestation and productivity of sesame (Sesamum indicum L.) in a Sudan Savanna zone of Nigeria. Ph.D Thesis, Department of Crop Production University of Maiduguri, Maiduguri. 2009; 145.

[54] Hanumanthappa DC, Mudalagiriyappa Rudraswamy Kumar GNV, Padmanabha K. Effect of weed management practices on growth and yield of cowpea (Vigna unguiculata L.) under rainfed conditions. Crop Research., (Hisar). 2012; 44(1/2): 55-58.

[55] Madukwe DK, Ogbuehi HC, Onuh MO. Effects of Weed Control Methods on the Growth and Yield of Cowpea (Vigna unguiculata (L.) Walp.) Under Rain-Fed Conditions of Owerri. American Eurasian Journal Agriculture and Environmental Science. 2012; 11: 1426-1430.

[56] Fontes JRA, Goncalves JRP, Morais RR de. Cowpea tolerance to oxadiazon. Indian Journal of weed science. 2010; 40(1): 110-115. 